\title{
Dr. Suresh C. Gupta: First Among Equals
}

\author{
Rajeev B. Ahuja' \\ ${ }^{1}$ Department of Plastic and Aesthetic Surgery, Sir Gangaram \\ Hospital, New Delhi, India
}

Indian J Plast Surg 2021;54:253-256.

\section{Nyaymatma Balheenien Labhya}

(Self-realization cannot be achieved by the weak)

A former President of the Association of Plastic Surgeons of India (APSI) and Chairman of APSI Trustees, Dr. Suresh Chand Gupta, who brought the World Congress of International Confederation for Plastic Reconstructive and Aesthetic Surgery (IPRAS) to the country, was a true icon of Indian plastic surgery (-Fig. 1).

On October 5, 1933, in Aligarh, he was born to Rai Bahadur Shiv Prasad, the Collector of Aligarh, a landowner who also owned cotton ginning mills at Hathras. His initial schooling was at the prestigious Modern School, Barakhamba Road, New Delhi ( - Fig. 2). This school was set up in 1920 by Lala Raghubir Singh, a philanthropist who desired an institution that combined the "best of ancient Indian tradition with the needs of the times." It was the first private and coeducational school established in Delhi after the capital of the British Raj shifted to the city. ${ }^{1}$ Dr. Gupta epitomized the school motto quoted above.

\section{Academic Career}

Dr. Gupta had a distinguished academic career and graduated in 1955 from Medical College, Agra, with Gold Medal and Honours. He subsequently went on to complete MS (General Surgery) in the year 1958 from the same college. From 1958 to 1960, he worked at the Irwin Hospital (now LNJP Hospital), New Delhi, with the legendary Dr. S.K. Sen. He was introduced to plastic surgery by a person no less than Sir Harold Gillies in 1959 at Jaipur. His interest saw him seeking plastic surgery training in the UK. From 1960 to 1965, he worked at East Grinstead (England) in Plastic and Reconstructive Surgery as a Senior Registrar. During his tenure there, he published a seminal article on breast reduction. ${ }^{2}$ When he returned to India, he was a full member of the British Association of Plastic Surgeons (BAPS).

On coming back to India in 1965, he joined Irwin Hospital (till 1968) and Sir Gangaram Hospital, New Delhi, as a Hon. Consultant. Around the same time, he also joined the Northern Railway Hospital in New Delhi. During the Indo-Pak

published online

September 16, 2021
DOI https://doi.org/

$10.1055 / \mathrm{s}-0041-1734578$ ISSN 0970-0358
Address for correspondence Rajeev B. Ahuja, MS, MCh, Department of Plastic and Aesthetic Surgery, Sir Gangaram Hospital, Rajinder Nagar, New Delhi-110 060, India (e-mail: rbahuja@gmail.com).

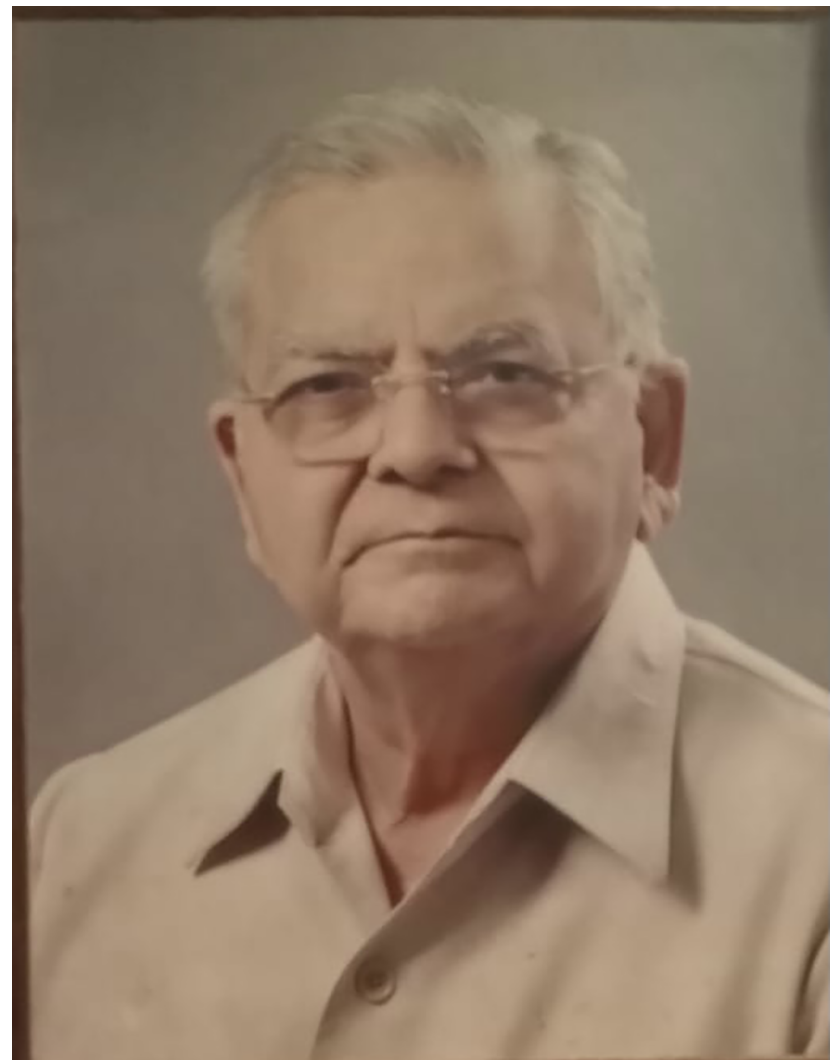

Fig. 1 Dr. Suresh C. Gupta (05.10.1933-04.11.2020).

war that year, he was also appointed as a Hon. Consultant to the Indian Armed Forces. He started the "Delhi Plastic Surgery Clinic," the only dedicated private clinic for plastic surgery at that time, 1971, at his residence, Greater Kailash.

He was always a keen learner, and in 1981, he attended the first ever microsurgery workshop organized in Delhi ( - Fig. 3a), where Prof. Edgar Biemer was a part of the faculty. Then, the following year, he visited Prof. Biemer in Munich to train further in microsurgery skills ( $\mathbf{- F i g}$. $\mathbf{3 b}$ ). That was the start of a long-standing friendship between them. He was

(C) 2021. Association of Plastic Surgeons of India.

This is an open access article published by Thieme under the terms of the Creative Commons Attribution-NonDerivative-NonCommercial-License, permitting copying and reproduction so long as the original work is given appropriate credit. Contents may not be used for commercial purposes, or adapted, remixed, transformed or built upon. (https://creativecommons.org/licenses/by-nc-nd/4.0/).

Thieme Medical and Scientific Publishers Pvt. Ltd. A-12, 2nd Floor, Sector 2, Noida-201301 UP, India 


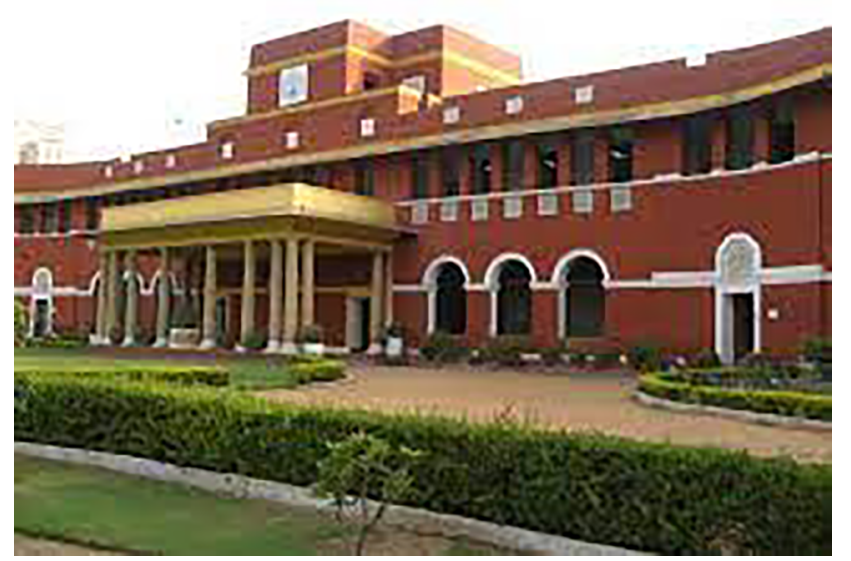

Fig. 2 Modern School, Barakhamba Road, New Delhi.
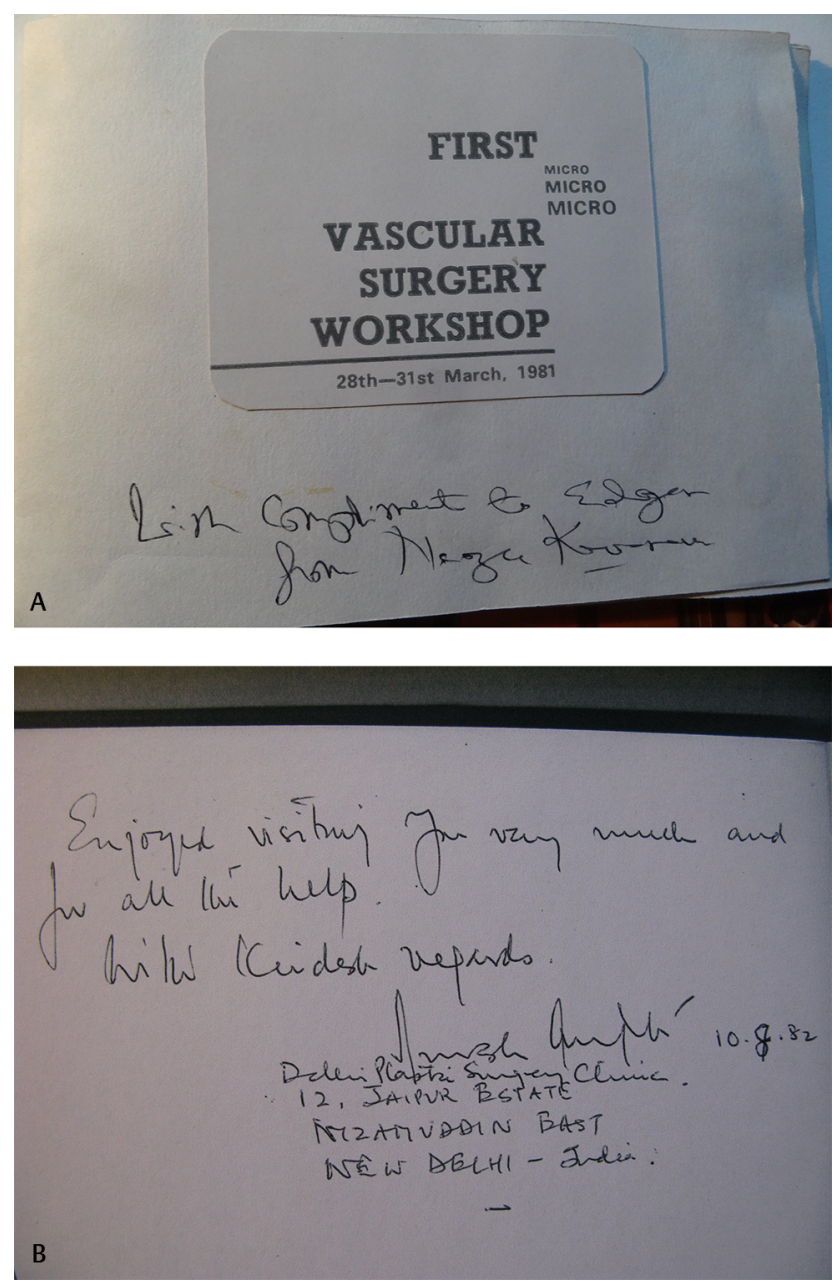

Fig. 3 (A) A sticker from the first microsurgery workshop in India. (B) An entry in the guest diary at Munich Hospital in 1982 (photos courtesy Prof. Edgar Biemer).

truly one of the pioneers of microsurgery in India. Thereafter, he set up a microsurgical laboratory at Sir Gangaram Hospital to practice and train other younger colleagues. Dr. Rakesh Khazanchi, current President APSI, recalls that once he had taken a rat to him in a shoebox to learn a venous anastomosis.

\section{Leading the Societies}

Dr. Suresh Gupta was elected President of the APSI in 1977 at the early age of 44 years. In the same year, he along with Dr. I.K. Dhawan, Lt. Col. P.M.L. Kathpalia, Dr N.C. Madan, Dr. S.S. Sethi, Dr. Vimla Rajan, and Dr. S.C. Almast formed the "Association of Plastic Surgeons of India-Delhi Chapter" and got it registered. Thus, the Delhi Chapter of APSI got registered independently even before the parent society! Dr. Suresh Gupta was its first President. The Delhi Chapter of APSI went into dormancy after being active for a few years before resuming operations in 1996. During the APSI Presidency of Admiral J.C. Sharma, it was once again revived by Brig. L.P. Sadhotra (who became the Treasurer) and Dr Rajeev B. Ahuja (who became the Secretary), with the active support of Dr Suresh Gupta (who provided the registration documents) and the blessings of Rear Admiral J.C. Sharma.

He was not only the first aesthetic surgeon of India but also enthusiastic about establishing this specialty in India. Although the Indian Association of Aesthetic Plastic Surgeons (IAAPS) was registered in September 1995, it languished for want of enough plastic surgeons interested or trained in aesthetic surgery. The few initial members of the Association in 1999 requested Dr. Suresh Gupta to take over the reins and resurrect it. He invited Dr. Ian Jackson, Dr. Edgar Biemer, and Dr. Illouz to teach aesthetic surgery at various meetings. Dr. Gupta's bonding with Dr. Ian Jackson was also very strong ( - Fig. 4). Often on their trips to Delhi Dr. Jackson and Dr. Biemer would stay at Dr. Gupta's house. Such was the close bonding with Dr. Biemer that Dr. Gupta was invited to the 60th birthday celebrations of Dr. Biemer in the year 2000, an event attended by top microsurgeons from around the world ( - Fig. 5 ).

Dr. Gupta was also active in international societies. He served on the executive body of the IPRAS, representing India and East. In 1987, he organized the World Congress of IPRAS, which was a resounding success. The Chief Guest at the Inaugural Ceremony was Shri Rajiv Gandhi, The Prime Minister of India ( - Fig. 6). The President of India,

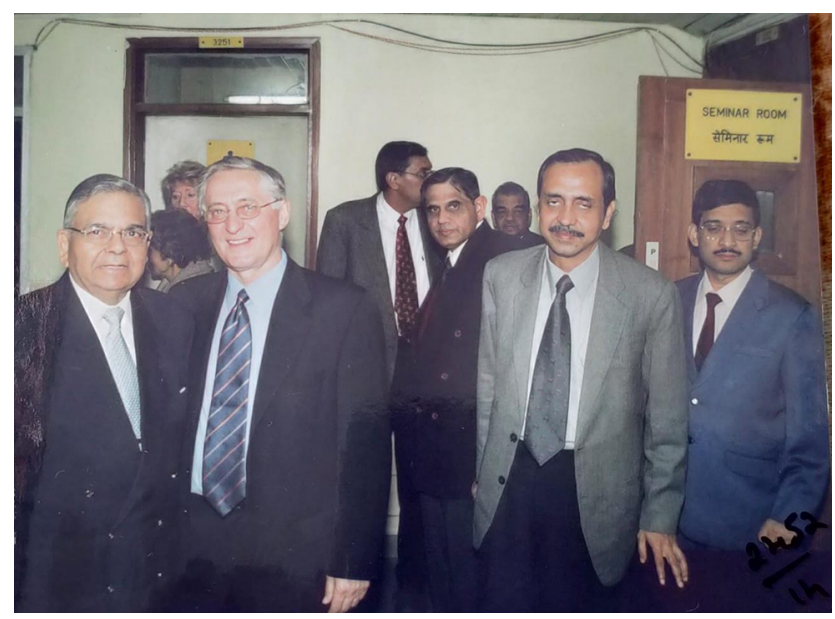

Fig. 4 During a visit of Dr. Ian Jackson to Delhi in 2004. At Army R \& R Hospital with Association of Plastic Surgeons of India (APSI)-Delhi Chapter members. 
Shri Giani Zail Singh, hosted a reception for the delegates at the Rashtrapati Bhawan ( - Fig. 7). From the savings of this International Congress, he initiated two fellowships (national and international) to help young plastic surgeons to travel for advanced training. From 1987 to 1996, he served as Director of the International Foundation of Plastic Surgery. Dr. Suresh Gupta was also the President of the IPRAS 2009 Congress, chaired by me in Delhi (-Fig. 8). In 2011, he was appointed as the Chairman of the Board of Trustees of APSI, a position he was still holding.

\section{Landmark Supreme Court Judgement}

Dr. Suresh Gupta will be remembered forever for the landmark 2004 Supreme Court judgment, where the criminal liability of a surgeon was redefined, and this decision came as a boon for the surgical profession in consumer liability $^{3}$

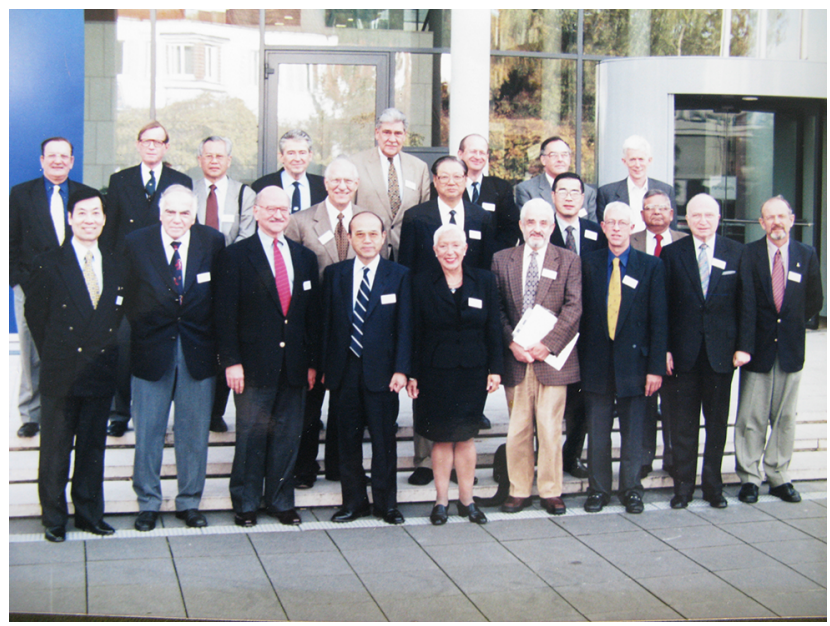

Fig. 5 Prof. Edgar Biemer's 60th birthday party in Munich in the year 2000 (photo courtesy Dr. Biemer).

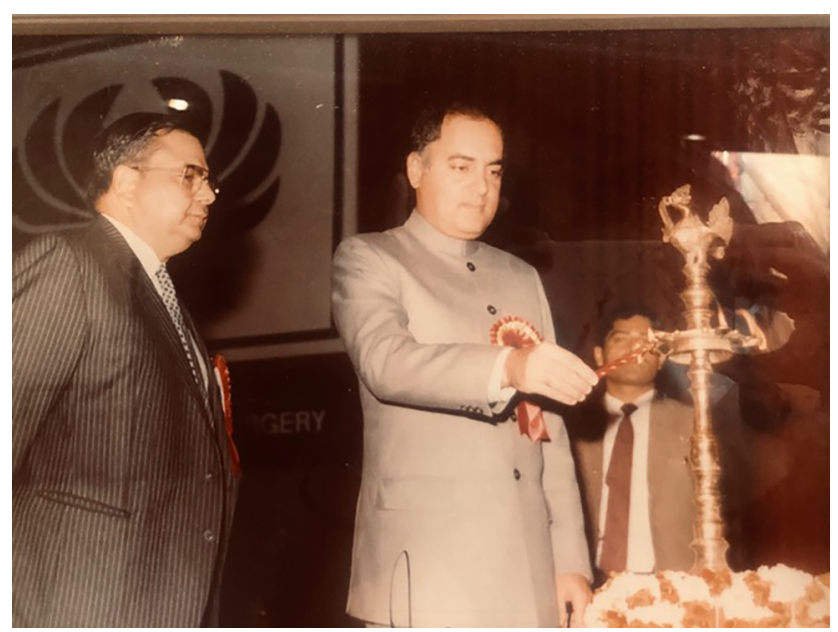

Fig. 6 Inauguration ceremony of International Confederation for Plastic Reconstructive and Aesthetic Surgery (IPRAS) 1987 Congress with Shri Rajiv Gandhi, the Prime Minister of India, as the Chief Guest.

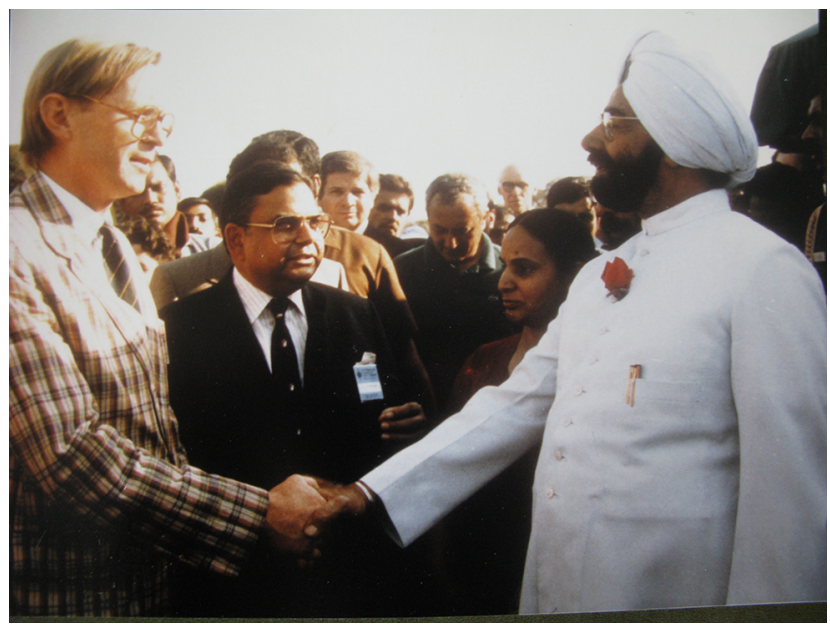

Fig. 7 Reception at the Rashtrapati Bhawan in 1987 during the International Confederation for Plastic Reconstructive and Aesthetic Surgery (IPRAS) (1987) Congress. Dr. Suresh Gupta and Prof. Edgar Biemer with President Shri Giani Zail Singh (photo courtesy Dr. Biemer).

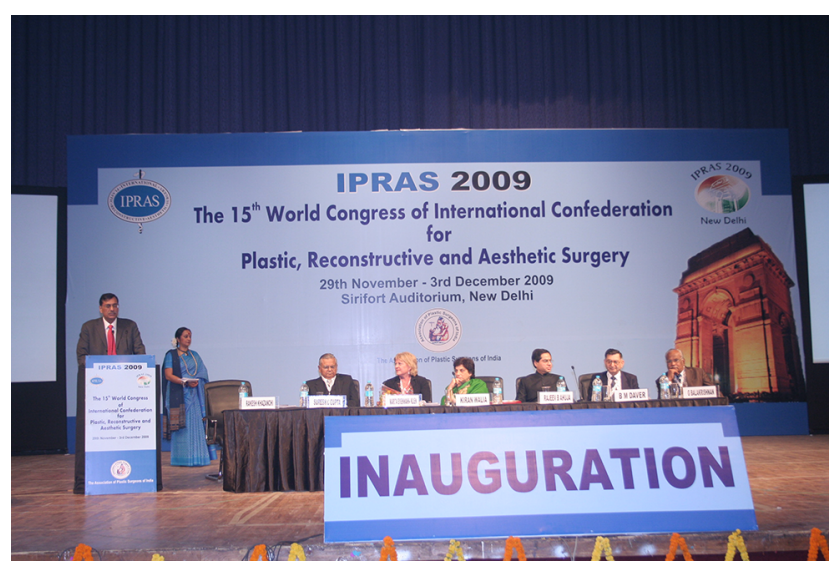

Fig. 8 Inaugural ceremony of International Confederation for Plastic Reconstructive and Aesthetic Surgery (IPRAS) 2009. Chief guest is Ms. Kiran Walia, Hon'ble Minister for Health. Govt. of NCT of Delhi.

\section{A Keen Golfer and Philanthropist}

Dr. Suresh Gupta was also very active in the Rotary club (Delhi Qutub) and in the India chapter of an international charitable NGO, The Kiwani's Club of New Delhi. For this NGO, he conceptualized and set up a dedicated artificial limb center in Delhi. The NGO was started by a very elite group of industrialists, bureaucrats, retired Chief of Staffs of the armed forces, etc.

Dr. Suresh Gupta was a keen golfer, and he played at the Delhi Golf Club (DGC) over the weekends, as he never worked on weekends! I fondly remember having a few lunch meetings with him at the DGC when I was the Secretary of APSI. "On his return from the UK, the work was minimal, and he spent his time learning golf," recalls Dr. Ashok Gupta, his son. "He would practice till he succeeded and was always imbibing finer points of the game."

A man of impeccable taste, he thrived in dressing as elegantly as he conducted himself. In his son's words, "his 
passion and in-depth knowledge of Hindustani classical music, which was self-taught, reached the level and expertise of a highly educated advanced listener, who could appreciate the depth, range, and perfection of this great skill/art." His passion for well-prepared food was also notable, and he always served a teetar (partridge) prepared by a special chef in Jama Masjid on all his birthday parties. I am a witness to some of the who's who of Delhi who attended these parties.

Dr. Gupta married Ms. S.R. Gupta on November 22, 1959. Mrs. Gupta retired as an Associate Professor of Physiology in 1984 from All India Institute of Medical Sciences (AIIMS). They have three children, Ashok, a vascular surgeon, Aruna who works in California in health services, and Nalini, who works in telecommunications and data development. They have five grandchildren.

\section{Untimely Demise}

A thorough professional, Dr. Gupta literally worked till the last day. He was conferred the Plastic Surgeon of the Year award (2020) by APSI, but he unfortunately could not receive it, as APSICON was cancelled in 2020. Last year, Dr. Gupta wrote a letter to the President of APSI, expressing his wish to donate Rs 20 Lakhs to start a teaching activity; sadly, he passed away before he could be formally informed of the Executive Committee's approval.

We pray for the departed soul.

\section{Conflict of Interest}

None declared.

\section{Acknowledgments}

I am grateful to Dr. Ashok Gupta (Dr. Suresh Gupta's son) and Prof. Edgar Biemer for their contribution to these memoirs and for some photos. Fig. 4 was graciously provided by Brig. P.S. Bhandari.

\section{References}

1 Modern School (New Delhi). Available at: https://en.wikipedia.org/wiki/Modern_School_(New_Delhi). Accessed June 14, 2021

2 Gupta SC. A critical review of contemporary procedures for mammary reduction. Br J Plast Surg 1965;18:328-335

3 Supreme Court of India. Dr. Suresh Gupta vs Govt. Of N.C.T. Of Delhi \& Anr on 4 August, 2004. Available at: https://indiankanoon.org/doc/650550/. Accessed May 20, 2021 